Article

\title{
The Physical and Chemical Properties of Soil Crust in Straw Checkerboards with Different Ages in the Mu Us Sandland, Northern China
}

\author{
Juan Wang ${ }^{1, *}$ and Rui Wang ${ }^{2}$ \\ 1 College of Hydraulic Science and Engineering, Yangzhou University, Yangzhou 225009, China \\ 2 Agriculture College, Ningxia University, Yinchuan 750021, China \\ * Correspondence: wangjuan@yzu.edu.cn
}

Received: 4 July 2019; Accepted: 26 August 2019; Published: 30 August 2019

\begin{abstract}
Straw checkerboards, as a mechanical sand barrier, are one of the most important engineering measures for sand control and vegetation restoration. In this study, we characterized the physical and chemical properties of soil crust treated with straw checkerboard in the Mu Us Sandland, Northern China, and investigated the mechanism of sand stabilization and revegetation in the arid area. We collected soil crust from $1.0 \times 1.0 \mathrm{~m}$ straw checkerboards after revegetation intermittently over 10 years, and then measured properties such as soil particle size composition, bulk density, soil nutrients, $\mathrm{pH}$, and other indicators in the laboratory. During the progress of straw checkerboard treatment, the results showed a significant decrease in percentage of soil crusts sand and a corresponding increase in the portion of silt and clay with straw checkerboard treatment years. The age of straw checkerboard treatment was positively correlated with soil nutrients, such as organic matter, total $\mathrm{N}$, total $\mathrm{P}$, total $\mathrm{K}$, available $\mathrm{N}$, available $\mathrm{P}$, and available $\mathrm{K}$. While $\mathrm{pH}$ showed a slightly rising trend, electrical conductivity (EC) was negatively correlated with crust life. The number of plant species has significantly changed, herbaceous vegetation succession being replaced by shrubs over 10 years, and vegetation coverage peaked at the sixth year. This study can represent a successful example of restoration in arid desert regions, thereby supplying more theoretical basis for sand fixation and dessert restoration.
\end{abstract}

Keywords: Mu Us Sandland; physical characteristics; chemical characteristics; soil crust; straw checkerboard

\section{Introduction}

Straw checkerboards are widely used as a cheap and effective way to control sand dunes in China. The checkerboards, with a usual size of $1.0 \times 1.0 \mathrm{~m}$, can increase underlying surface roughness and reduce near-surface wind velocity, thereby stabilizing the sand dune surface [1]. After a certain period of straw checkerboard treatment, a soil crust layer in the surface is produced. Soil crust is a major structural feature of soil surface, especially in semi-arid and arid regions [2], where physical and biological crusts are the main types [3]. With straw checkerboards or sand prevention and control measures, the physical crust usually forms at windward slope during the wind season, and then strengthens by raindrop splashing. Afterwards, the invasion and development of drought-resistant microorganisms help to form a biological crust gradually [4]). Soil crusts play a major role in water and nutrient fluxes in arid and semi-arid regions, contributing to the spatial arrangement of vegetated and open areas [5,6]. There are some publications on the composition of soil crusts in arid and semi-arid regions. The importance of soil crust development in ecological functioning in arid and semi-arid regions is widely recognized $[7,8]$. In the arid desert regions of China, soil crusts are common on the shifting sand dunes and have been stabilized. The properties of crusts have been analyzed in detail by 
several researchers in sandy soil from Shapotou region, China, where straw checkerboards have been extensively used [9]. Studies have been conducted on the crust formation mechanism and the effects of sand-binding vegetation. It has been found that the crust can improve the soil nutrient content, enhance soil water-holding capacity, and promote vegetation growth and succession. Soil crusts also have suitable soil and water conservation features [10].

Due to drought and low fertilization, especially a lack of $\mathrm{N}$ and $\mathrm{P}$, soil crusts are considered to be nitrogen fixers [5]. A study found that soil crusts can dramatically increase the surface $5 \mathrm{~cm}$ of soil organic matter content [11]. Another study showed that crust silt and clay content, organic matter, and total and available nutrient content in nutrient efficiency is higher than the sand in Ordos, and soil crust with a positive correlation with crust thickness [12].

Some studies have assessed the role of soil crusts in improving the structure and function of desert ecosystems $[8,13]$. The results confirm that soil crust plays an important role in protecting soil from water and wind erosion [14,15], and enhancing soil stability and fertility [16,17]. Soil crusts on the surface improve soil physical and chemical properties, and form the basis of their ecological functions [18]. Crust appearance, not only affecting soil structure, function, and productivity, can also increase soil stability, water-holding capacity, and soil fertility, as well as effectively prevent the movement of sand and increase the arid zone ecosystems and biodiversity [19]. It plays a decisive role in desert vegetation succession, and it is an important foundation for the vegetation succession process [20]. However, several studies have demonstrated that the continuous deposition of fine sand particles, including atmospheric dust, on the stabilized sand surface provides abundant material for soil crust formation [21]. Many researchers have focused on the studies of the crust desertification of ecosystem structure and function and its role in desertification control [22] (Guo et al., 2007), confirming that biological crusts can fix atmospheric $\mathrm{N}$ and increase soil organic matter content. Some scholars, through physical and chemical analysis of soil crusts, have discussed the performance differences in the process of crust formation [9]. Previous studies have proved that straw checkerboards have a significant effect on sand fixing and vegetation restoration [22-24], but no systematic research has been conducted to analyze and explore the changes of physical and chemical properties in soil crust development with the age of straw checkerboards in Mu Us Sandland. Studies of soil crust physical and chemical properties, treated by straw checkerboards in different years, have not yet been reported. The objectives were to: (1) Study the formation as well as physical and chemical properties of soil crust in straw checkerboards of different years in the Mu Us Sandland, and (2) to reveal the desertification reversal process with soil crust formation by field investigation and laboratory analysis between soil crust and soil factors. The results of this study will supply fundamental theory for restoration in arid desert regions.

\section{Materials and Methods}

\subsection{The Study Area}

The study was conducted in Baijitan nature protection zone, in the Ningxia Hui Autonomous Region on the west edge of the $\mathrm{Mu}$ Us Sandland $\left(37^{\circ} 55^{\prime} \mathrm{N}\right.$ and $106^{\circ} 30^{\prime} \mathrm{E}$, elevation $=1320 \mathrm{~m}$ ). $\mathrm{Mu}$ Us Sandland is one of China's four big desserts with an area of 4.22 million ha, mainly located in the concave ground of lacustrine flood plain between Ordos Plateau and the Loess Plateau. It has a temperate, continental semi-arid monsoon climate regime, and the annual frost-free period is approximately 157 days, mean annual potential evaporation is $2862.2 \mathrm{~mm}$, yearly average precipitation is approximately $206.2 \mathrm{~mm}$, about $80 \%$ of this falling between June and September. The yearly average temperature is $8.8^{\circ} \mathrm{C}$, with January (the coldest month) averaging $-6.9^{\circ} \mathrm{C}$, and July (the warmest month) $24.3^{\circ} \mathrm{C}$. The protected areas concentrate in arid sand, desert grasslands, and sand dunes; the predominant native plant species are Nitraria tangutorum, Artemisia arenaria, Hedysarum scoparium, Agriophyllum squarrosum, and Oxytropis aciphylla. The main soil types are Sandy soil and Sierozem. 
The soil formation process is unstable and soil development is very weak. The straw checkerboards have been here more than 20 years and have radically improved sand fixation and vegetation recovery.

\subsection{Sample Collection and Treatment}

GPS positioning was used in protected areas to collect soil crust from the years 2001 to 2014 after treatment with straw checkerboards of 0, 2, 4, 6, 8, and 10 years in August 2014. The treatments A, B, C, D, E, and F represent 0-year mobile sand (2014), 2-year soil crust (2012), 4-year soil crust (2010), 6-year soil crust (2008), 8-year soil crust (2006), and 10-year soil crust (2004), respectively. Take the 2-year soil crust (2012) as an example, it means the straw checkerboards established at 2012, and when we collected the samples, it was 2 years old. We surveyed five points of each treatment; the soils were sampled from a $0-5 \mathrm{~cm}$ depth in each point and were taken to the laboratory and then air-dried and hand-sieved through a $2 \mathrm{~mm}$ sieve prior to laboratory analysis. The particle sizes of the soil samples were determined by MS2000 Malvern Laser Analyzer (Malvern Instrument Company, UK). Moisture was determined by gravimetric with oven drying at $105{ }^{\circ} \mathrm{C}$ for at least $8 \mathrm{~h}$. Soil bulk density was done using stainless steel cylinders with a volume of $50 \mathrm{~cm}^{3}$ (diameter $5 \mathrm{~cm}$, height $2.5 \mathrm{~cm}$ ) to assay at each sampling point. The soil crust thickness was evaluated at soil profile by a steel ruler. Electrical conductivity (EC) was measured by a portable conductivity meter (Cole-Parmer Instrument Company, Vernon Hills, IL, USA). The $\mathrm{pH}$ was determined by measuring the $\mathrm{pH}$ of soil-water slurry $(1: 5, \mathrm{w} / \mathrm{v}$, weight to distilled water ratio) by using $\mathrm{pH}$ meters (Leici PHS-3C, Shanghai, China). Organic matter $(\mathrm{OM})$ was measured by the dichromate oxidation method [25]. Total nitrogen (TN) was by the Kjeldahl procedure [26], total phosphorus (TP) was by UV-1601 spectrophotometer following Lehtola et al. [27], and total potassium (TK) was by flame photometry [28]. Available nitrogen (AN) was determined by the alkaline diffusion method, available phosphorus (AP) was determined by the Bray method, and available potassium (AK) was measured by the FP-640 flame photometer [29]. The main plant species were recognized artificially, and the vegetation coverage was calculated from the averaged leaf area index (LAI) data according to Boer and Puigdefábregas [30], and the LAI was measured by the ACCUPAR LP-80 Ceptometer (Decagon Devices, Inc., Pullman, WA, USA).

\subsection{Statistical Methods}

The distribution of the groups were firstly tested by Shapiro-Wilk method against a normality hypothesis using SAS [31]. The results showed that all of the groups could be described by the normal distribution. Statistical differences among groups were determined by analysis of variance (ANOVA) using the SAS 8.1 software (SAS Institute Inc., Cary, NC, USA), followed by the least significant difference (LSD) test for multiple comparisons among groups. A difference returning a $p$-value less than $5 \%(p<0.05, n=5)$ was considered statistically significant.

\section{Results}

\subsection{Soil Particle Size}

Generally, the fractions of silt and clay are considerably higher in soil crust, while coarse sand is higher in the mobile sand. At the beginning of treatment by straw checkerboard, particles of mobile sand were concentrated in sand part, accounting for $99.17 \%$, the remainder being silt and clay (Table 1 ). This indicates that in the original state, the fixation ability of mobile sand was very limited, and the silt and clay were almost blown away by the wind. After 2 years of treatment by straw checkerboards, the percent of sand dropped, within which the fraction of 1-0.25 $(\mathrm{mm})$ part decreased $29 \%$, while $0.25-0.05(\mathrm{~mm})$ part increased $18 \%(p<0.05)$. Compared with sand dunes, the percent of silt and clay had a significant increase $(p<0.05)$. This result is consistent with the findings of Zhang et al. [32]. Straw checkerboards can reduce land surface wind and decrease its ability of carrying sand, so the silt and clay can subside in the area of the straw checkerboard surface. During the 6 years of treatment, compared with shifting sand, the percentage of 1-0.25 ( $\mathrm{mm})$ part sand was largely decreased from 
69.06 to $11.14 \%$, while silt significantly increased from 0.12 to $43.08 \%$, and clay increased from 0.71 to $13.48 \%(p<0.05)$. After the duration over 6 years, the percent of sand became stabilized, ranged from 43.44 to $51.31 \%$, and silt and clay had a slight decrease, silt from 43.08 to $36.05 \%$, clay from 13.48 to $11.49 \%$ (Table 1).

Table 1. Soil particle size of soil crust in straw checkerboard with different treated years.

\begin{tabular}{cccccccccc}
\hline \multirow{2}{*}{ Treatments } & \multicolumn{3}{c}{ Sand (\%) } & \multicolumn{3}{c}{ Silt (\%) } & \multicolumn{3}{c}{ Clay (\%) } \\
\cline { 2 - 9 } & $\mathbf{> 0 . 2 5} \mathbf{~ m m}$ & $\mathbf{0 . 2 5 - 0 . 0 5} \mathbf{~ m m}$ & Total & $\mathbf{0 . 0 5 - 0 . 0 2} \mathbf{~ m m}$ & $\mathbf{0 . 0 2 - 0 . 0 0 2} \mathbf{~ m m}$ & Total & $\mathbf{0 . 0 0 2 - 0 . 0 0 1} \mathbf{~ m m}$ & $<\mathbf{0 . 0 0 1} \mathbf{~ m m}$ & Total \\
\hline A & $69.06 \pm 0.96 \mathrm{a}$ & $30.11 \pm 0.55 \mathrm{f}$ & 99.17 & $0.03 \pm 0.01 \mathrm{f}$ & $0.09 \pm 0.01 \mathrm{f}$ & 0.12 & $0.24 \pm 0.01 \mathrm{f}$ & $0.47 \pm 0.01 \mathrm{f}$ & 0.71 \\
B & $40.52 \pm 0.59 \mathrm{~b}$ & $48.45 \pm 0.61 \mathrm{a}$ & 88.97 & $7.23 \pm 0.51 \mathrm{e}$ & $1.65 \pm 0.03 \mathrm{e}$ & 8.88 & $1.13 \pm 0.03 \mathrm{e}$ & $1.02 \pm 0.03 \mathrm{e}$ & 2.15 \\
C & $13.87 \pm 0.33 \mathrm{c}$ & $43.56 \pm 0.58 \mathrm{~b}$ & 57.43 & $29.31 \pm 0.65 \mathrm{~d}$ & $2.81 \pm 0.17 \mathrm{~d}$ & 32.12 & $4.76 \pm 0.23 \mathrm{~b}$ & $5.69 \pm 0.14 \mathrm{~d}$ & 10.45 \\
D & $11.14 \pm 0.15 \mathrm{e}$ & $32.30 \pm 0.32 \mathrm{e}$ & 43.44 & $36.81 \pm 0.81 \mathrm{a}$ & $6.27 \pm 0.57 \mathrm{a}$ & 43.08 & $5.26 \pm 0.17 \mathrm{a}$ & $8.22 \pm 0.23 \mathrm{a}$ & 13.48 \\
E & $12.23 \pm 0.12 \mathrm{~d}$ & $39.08 \pm 0.48 \mathrm{c}$ & 51.31 & $32.01 \pm 0.43 \mathrm{c}$ & $4.04 \pm 0.28 \mathrm{c}$ & 36.05 & $4.51 \pm 0.37 \mathrm{c}$ & $8.13 \pm 0.29 \mathrm{~b}$ & 12.64 \\
F & $11.75 \pm 0.31 \mathrm{~d}$ & $37.80 \pm 0.34 \mathrm{~d}$ & 49.55 & $33.99 \pm 0.47 \mathrm{~b}$ & $4.97 \pm 0.32 \mathrm{~b}$ & 38.96 & $3.98 \pm 0.20 \mathrm{~d}$ & $7.51 \pm 0.37 \mathrm{c}$ & 11.49 \\
\hline
\end{tabular}

Note: The average values in a column with different letters are significantly different at $p<0.05$ by multiple comparisons $(n=5)$.

\subsection{Soil Crust Physical Properties}

The mobile sand bulk density is the largest, much more than $1.58 \mathrm{~g} \cdot \mathrm{cm}^{-3}$ in the new straw checkerboards, and it slightly reduced with the existence duration of straw checkerboards. For and after 6 years, material composition of the crust became stable, and resulted in consist bulk density of around $1.47 \mathrm{~g} . \mathrm{cm}^{-3}$ (Table 2). This indicates that the contribution of moss and leaves increased in the soil crusts in the treatment of straw checkerboards.

Table 2. The physical properties of soil crust after treatment by straw checkerboards.

\begin{tabular}{cccccc}
\hline Treatments & $\begin{array}{c}\text { Bulk Density } \\
\left(\mathbf{g . c m}^{-3} \text { ) }\right.\end{array}$ & $\begin{array}{c}\text { Soil Crust } \\
\text { Thickness (cm) }\end{array}$ & $\begin{array}{c}\text { Surface Soil } \\
\text { Moisture (\%) }\end{array}$ & $\begin{array}{c}\text { Soil } \\
\text { Porosity (\%) }\end{array}$ & $\begin{array}{c}\text { Capillary Water- } \\
\text { Holding Capacity } \\
\mathbf{( g . k g}^{-1} \text { ) }\end{array}$ \\
\hline A & 1.58 & 0 & 3.32 & 33.32 & 198.71 \\
B & 1.51 & 0.05 & 2.27 & 33.21 & 222.34 \\
C & 1.49 & 0.11 & 1.74 & 35.19 & 328.34 \\
D & 1.47 & 0.15 & 1.67 & 37.78 & 388.38 \\
E & 1.47 & 0.17 & 1.66 & 37.59 & 397.37 \\
F & 1.46 & 0.31 & 1.53 & 36.88 & 425.51 \\
\hline
\end{tabular}

Crust thickness increased progressively from 0 to $0.31 \mathrm{~cm}$, indicating that the recovery time had a significant effect on the thickness of the crust. Mobile sand had no crust, but 2 years later, a thin layer of physical crust about $0.05 \mathrm{~cm}$ appeared; after 4 years, on the basis of physical crust emerged a small amount of biotic crust, and over 10 years, the crust thickness increased up to $0.31 \mathrm{~cm}$ (Table 2).

The soil surface moisture in the Mu Us Sandland is mainly contributed by rainfall, and affected by surface vegetation coverage. Table 2 shows that the surface soil moisture content of mobile sand was the highest, and decreased with straw checkerboard duration. The surface soil moisture reduced from 3.32 to $1.53 \%$ over 10 years. The decreasing surface soil moisture can be explained by vegetation consumption, with increase in vegetation cover, density, and species diversity.

Soil porosity markedly increased from 33.32 to $36.88 \%$, and capillary water-holding capacity doubled for the 10-year treatments (Table 2). This result is principally because the crust has a lot of expansion humic organic matter. Soil organic absorbent generally has up to five times water absorptivity of its own weight, which can hold more rainfall in the soil crust surface, and then uses it for lower biological growth and reproduction.

\subsection{Soil Crust Chemical Properties}

Soil $\mathrm{pH}$ is an important index of soil chemical property, and it directly affects soil fertility status and plant growth-a suitable $\mathrm{pH}$ range promotes the soil nutrient availability and transformation $[6,33]$. 
Soil $\mathrm{pH}$ increased with desertification reversal from 8.21 to 8.65 , but there was no significant difference among the initial 6 years, although it started to significantly change after 8 years of treatment. However, there are no changes in electric conductivity (EC) among treatments with different years (Table 3).

Generally, soil organic matter contents were significantly higher in the soil crust than in the mobile sand, and higher in thick crust than in thin crust (Table 3). With an increase in the age of straw checkerboard treatments, organic matter content consistently increased. Compared with the mobile sand, the content of organic matter in soil crusts treated for 2 years showed a slight increase. However, after 4 years of treatments, the content of organic matter doubled. From 4 years onward, the speed of increase became rather slow. Eventually, organic matter peaked at $2.65 \mathrm{~g} \cdot \mathrm{kg}^{-1}$ for 10 years. Starting at 4 years of treatment, organic matter exceeded $2 \mathrm{~g} \cdot \mathrm{kg}^{-1}$ in sand areas where organic matter was commonly less than $1 \%$. Our results show that straw checkerboards can promote vegetation recovery and the growth of crust in desert areas.

Soil crusts have the ability to improve soil chemical properties. Nitrogen is the most significant limiting factor for plant growth, and the nitrogen fixation is relatively limited in semi-arid regions. Therefore, in these areas, microorganisms in the soil crust composition should be the most important source of nitrogen. Among the period of straw checkerboard revegetation, nutrients (total N, P, K and available N, $\mathrm{P}, \mathrm{K}$ ) and $\mathrm{OM}$ had a positive linear trend with time since establishment of the checkerboards. (Table 3). 
Table 3. The nutrients of soil crust after treatment by straw checkerboards.

\begin{tabular}{|c|c|c|c|c|c|c|c|c|c|}
\hline Treat-Ments & $\mathrm{pH}$ & $\mathrm{EC}\left(\mathrm{ms} \cdot \mathrm{cm}^{-1}\right)$ & $\mathrm{OM}\left(\mathrm{g} \cdot \mathrm{kg}^{-1}\right)$ & $\mathrm{TN}\left(\mathrm{g} \cdot \mathrm{kg}^{-1}\right)$ & $\mathrm{TP}\left(\mathrm{g} \cdot \mathrm{kg}^{-1}\right)$ & TK $\left(g \cdot \mathrm{kg}^{-1}\right)$ & AN (mg.kg-1) & $\mathrm{AP}\left(\mathrm{mg} \cdot \mathrm{kg}^{-1}\right)$ & AK (mg. $\left.\mathrm{kg}^{-1}\right)$ \\
\hline $\mathrm{A}$ & $8.21 \pm 0.32 b$ & $0.13 \pm 0.12 \mathrm{a}$ & $0.85 \pm 0.01 \mathrm{f}$ & $0.45 \pm 0.32 d$ & $0.04 \pm 0.01 \mathrm{e}$ & $0.44 \pm 0.14 \mathrm{~d}$ & $2.11 \pm 1.52 \mathrm{e}$ & $1.11 \pm 0.77 \mathrm{e}$ & $189 \pm 13 c$ \\
\hline B & $8.27 \pm 0.27 b$ & $0.14 \pm 0.11 \mathrm{a}$ & $0.92 \pm 0.01 \mathrm{e}$ & $1.24 \pm 0.26 \mathrm{~d}$ & $0.12 \pm 0.08 \mathrm{e}$ & $0.76 \pm 0.06 c$ & $3.77 \pm 0.19 \mathrm{e}$ & $1.97 \pm 0.65 \mathrm{e}$ & $193 \pm 8 c$ \\
\hline C & $8.34 \pm 0.22 b$ & $0.13 \pm 0.13 a$ & $2.17 \pm 0.11 \mathrm{~d}$ & $1.66 \pm 0.10 \mathrm{~d}$ & $0.79 \pm 0.06 \mathrm{~d}$ & $0.79 \pm 0.03 c$ & $5.14 \pm 0.47 \mathrm{~d}$ & $3.21 \pm 0.46 \mathrm{~d}$ & $207 \pm 2 b$ \\
\hline $\mathrm{D}$ & $8.45 \pm 0.10 b$ & $0.13 \pm 0.11 \mathrm{a}$ & $2.42 \pm 0.02 c$ & $2.89 \pm 0.02 c$ & $0.98 \pm 0.04 c$ & $0.86 \pm 0.02 b$ & $6.22 \pm 0.22 c$ & $5.44 \pm 0.01 c$ & $215 \pm 5 b$ \\
\hline $\mathrm{E}$ & $8.61 \pm 0.07 a$ & $0.13 \pm 0.10 \mathrm{a}$ & $2.53 \pm 0.03 b$ & $2.92 \pm 0.01 b$ & $1.11 \pm 0.01 b$ & $0.87 \pm 0.01 b$ & $7.78 \pm 0.02 b$ & $5.46 \pm 0.01 b$ & $222 \pm 2 a$ \\
\hline $\mathrm{F}$ & $8.65 \pm 0.09 a$ & $0.13 \pm 0.10 a$ & $2.65 \pm 0.09 a$ & $2.97 \pm 0.02 a$ & $1.14 \pm 0.01 a$ & $0.93 \pm 0.03 a$ & $7.88 \pm 0.05 a$ & $5.73 \pm 0.03 a$ & $227 \pm 7 a$ \\
\hline
\end{tabular}

Note: $\mathrm{OM}=$ organic matter, $\mathrm{TN}=$ total nitrogen, $\mathrm{TP}=$ total phosphorus, $\mathrm{TK}=$ total potassium, $\mathrm{AN}=$ available nitrogen, $\mathrm{AP}=$ available phosphorus, $\mathrm{AK}=$ available potassium. The average values in a column with different letters are significantly different at $p<0.05$ by multiple comparisons $(n=5)$. 


\subsection{The Main Plant Succession Laws}

The main plant and vegetation cover in straw checkerboards with different years are concluded in Table 4. There were only a handful of Agriophyllum squarrosum on the sand dunes and the coverage was about $0.65 \%$. In the 2 years since establishment, vegetation began to settle, but the types of plant species were scarce and vegetation coverage was also small. The principal plants were annual dry plant species such as Agriophyllum squarrosum, Artemisia arenaria, and wheat from straw checkerboard, which were able to effectively take advantage of spring and summer rainfall to achieve rapid growth and complete life cycle. They became vegetation succession pioneer species in the barren desert habitats. By the fourth year of establishment, there was a gradual emergence of trifling amounts of Artemisia arenaria and Aristida adscensionis in the straw checkerboards, the plant crown was heavy and vegetation coverage increased to $17.45 \%$, which improved the stability of sand. In the 6-year straw checkerboards, Artemisia arenaria species expanded, the larvae Artemisia appeared, and Aristida adscensionis basically disappeared, while Suaeda salsa and Psammochloa villosa started to show up and the vegetation coverage reached to the highest of $35.30 \%$. After 8 years, the soothing herbs Agriophyllum squarrosum and Suaeda salsa disappeared and were replaced by drought-resistant species Calligonum mongolicum and Hedysarum scoparium, and the tall Artemisia arenaria also had part of the living space. Generally, the plant species diversity decreased and vegetation coverage dropped down to $22.66 \%$. It was hard to find herbs, as these were completely replaced by drought-tolerant shrub after 10 years later.

Table 4. The main plant and vegetation cover after treatment by straw checkerboards.

\begin{tabular}{ccc}
\hline Treatments & Main Plant & Vegetation Cover (\%) \\
\hline A & Agriophyllum squarrosum & 0.65 \\
B & Agriophyllum squarrosum, Artemisia arenaria, wheat & 5.50 \\
C & Agriophyllum squarrosum, Artemisia arenaria, Aristida adscensionis, Salsola & 17.45 \\
D & Agriophyllum squarrosum, Artemisia arenaria, Suaeda salsa, & 35.30 \\
E & Calligonum mongolicum, Psammochloa villosa & 22.66 \\
F & Artemisia arenaria, Calligonum mongolicum, Hedysarum scoparium & 23.80 \\
\hline
\end{tabular}

\section{Discussion}

It is meaningful for sand management to study the physical and chemical properties of the desert soil crust, because of its impacts on soil stability and erosion, atmospheric nitrogen fixation, plant nutrient uptake, soil-plant-water relations, water infiltration, and plant growth [20]. The soil crust plays an important role in the ecological environment, especially in arid and semi-arid ecosystems where nutrient hormone is deficient $[13,34]$.

Soil crusts can help to deposit enough clay and silt, and provide the moisture level for crust growth. Hence, soil crusts have a catalytic effect on soil development [35]. The soil crust can strengthen the surface roughness and enhance the wind-resistant ability of sand. It was found in long-term practice that the most obvious change of surface morphology was the formation of crust after the mobile dune was fixed [35]. Therefore, the formation of soil crusts represents an important change of the environment in desertification areas [16]. Crust generation and the development of new-formed crusts are the most primitive vegetation succession processes. Our present results are in accordance with that previously reported which showed an increase in the percentage of clay and silt and a corresponding decrease in sand during the process of treatment by straw checkerboards [15]. On mobile dunes, 2 years after establishment of straw checkerboards, physical soil crust on sand dunes formed, and biological soil crusts formed in 4 years.

Our results found that with the period of straw checkerboard treatment, bulk density and surface soil moisture were reduced, and soil crust thickness, soil porosity, capillary water-holding capacity were increased. Moreover, the $\mathrm{pH}$, organic matter, and nutrient content increased with crust years, reaching their highest in 10 years, and the lowest in 0 year mobile dunes, which is consistent with 
the studies of Fang et al. and Wang et al. [15,36]. The EC had no prominent change with crust years, which is in accordance with the results of $\mathrm{Li}$ et al. [37]. They also reported the accumulation of $\mathrm{CaCO}_{3}$ in the topsoil, which may explain the raised $\mathrm{pH}$ in our study.

The present results give a clear indication that physical and chemical properties play a very important role in soil crust fixation and development. This may be attributed to the fact that soil crusts have a stronger ability to slow down wind speed and capture plant litter and fine soil particles because they have dense, limp branches and grow vigorously [13]. It was found that the vegetation coverage and main plant types increased remarkably from 0 to 6 years of treatment, and peaked in the sixth year. Afterwards, the vegetation types and coverage reduced slowly, which might have been induced by vegetation types in the straw checkerboard with succession from herbs to shrub-grass, and a change in vegetation morphology both aboveground and underground. Besides, the soil water and nutrient competition between vegetation would have induced vegetation self-thinning. This result is in agreement with a study in Ningxia by Zhang [32]. This result also confirms the view of Guo et al. in that establishment of planted vegetation was beneficial to soil crust formation and development in semi-arid desert [13].

It was found in our study that after 6 years of straw checkerboard treatment, the clay content of the soil crust peaked and vegetation types in the straw checkerboards had succession from herbs like Agriophyllum squarrosum and Artemisia arenaria to shrub-grass like Calligonum mongolicum. The root depth and root distribution types had a great influence on soil crust clay, especially in herbaceous vegetation; Agriophyllum squarrosum has mainly shallow fibrous roots, which had a critical role in the formation of the crust clay promotion. As shrub invasion occurred, the increase in shoot height and root system promoted the clay content, and the role of wind and surface soil moisture may became the main limits of clay content. The results demonstrate that the increase in soil fertility (available $\mathrm{N}, \mathrm{P}, \mathrm{K}$ and soil organic matter) after revegetation was roughly associated with increasing species diversity and coverage (Table 3). Consequently, it is suggested that revegetation of mobile sand dunes has significantly improved the soil environment, both physio-chemically and biologically. After a series of changes in physical, chemical, and biological characteristics, the desert soil will have the basic elements and plant growth conditions, and lay a solid foundation for the next succession process. Thus, straw checkerboards are an extremely effective approach to combat desertification in the arid desert area with extreme water shortage and degraded vegetation.

\section{Conclusions}

The straw checkerboards had a significant role in promoting mobile sand fixation and soil crust formation. It was found in this study that on mobile dunes, physical soil crust can form within 2 years and some biological soil crust within 4 years. The percent of clay and silt increased with the age of straw checkerboards, while bulk density decreased. The soil crust thickness, soil porosity, capillary water-holding capacity, as well as soil nutrient content were positively correlated with straw checkerboard duration, reaching their highest in 10 years. The vegetation coverage and the number of main plant types increased with time, and peaked at in the sixth year, then decreased. Vegetation types in the straw checkerboards had succession from herbs to shrub-grass. Generally speaking, straw checkerboards can be considered as a main technique for the revegetation of mobile sand dunes and used widely in arid desert areas.

Author Contributions: J.W. and R.W. conceived and designed the experiments; R.W. performed the experiments; J.W. analyzed the data; J.W. contributed reagents/materials/analysis tools; J.W. wrote the paper.

Funding: This research was funded by the National Natural Science Foundation of China (Grants No. 51609209) and the Natural Science Foundation of Jiangsu Province (Grants No. BK20160471). We thank our colleagues for their comments on this paper, and the journal's editors and anonymous reviewers for their critical review and comments on an earlier version of this manuscript.

Conflicts of Interest: The authors declare no conflict of interest. 


\section{References}

1. Qu, J.; Zu, R.; Zhang, K.; Fang, H. Field observations on the protective effect of semi-buried checkerboard sand barriers. Geomorphology 2007, 88, 193-200. [CrossRef]

2. Graef, F.; Stahr, K. Incidence of soil surface crust types in semiarid Niger. Soil Tillage Res. 2000, 55, $213-218$. [CrossRef]

3. Hawkes, C.V.; Flechtner, V.R. Biological soil crust in a xeric florida shrubland: Composition, abundance, and spatial heterogeneity of crusts with different disturbance histories. Microb. Ecol. 2002, 43, 1-12. [CrossRef] [PubMed]

4. Fang, H.; Qu, J.; Zu, R.; Zhang, K.; Li, Q. Research on Effect of Sand Prevention and Control Engineering on Formation of Physical Crust. J. Soil Water Conserv. 2005, 19, 17-20. (In Chinese)

5. Kang, J.; Zhao, M.; Tan, Y.; Zhu, L.; Bing, D.; Zhang, Y.; Tong, S. Sand-fixing characteristics of Carex brunnescens and its application with straw checkerboard technique in restoration of degraded alpine meadows. J. Arid Land 2017, 9, 651-665. [CrossRef]

6. Li, X.; Zhou, R.; Jiang, H.; Zhou, D.; Zhang, X.; Xie, Y.; Gao, W.; Shi, J.; Wang, Y.; Wang, J.; et al. Quantitative analysis of how different checkerboard sand barrier materials influence soil properties: A study from the eastern edge of the Tengger Desert, China. Environ. Earth Sci. 2018, 77, 481. [CrossRef]

7. Li, Y.; Cui, J.; Zhang, T.; Okuro, T.; Drake, S. Effectiveness of sand-fixing measures on desert land restoration in Kerqin Sandy Land, northern China. Ecol. Eng. 2009, 35, 118-127. [CrossRef]

8. Yang, H.; Liu, L.; Li, X.; Wei, Y.; Li, X.; Jia, R. Water Repellency of Biological Soil Crusts and Influencing Factors on the Southeast Fringe of the Tengger Desert, North-Central China. Soil Sci. 2014, 179, 424-432. [CrossRef]

9. Chen, X.; Duan, Z. The physical and chemical characteristics of different soil crusts in arid desert area of China. J. Arid Land Resour. Environ. 2008, 22, 134-138. (In Chinese)

10. Song, Y.; Yan, P.; Zhang, H.; Meng, X. Recent progress and some existing problems in the study on the desert microbiotic crusts. Arid Zone Res. 2004, 21, 439-442. (In Chinese)

11. Zhang, Y.; Yang, W.; Wang, X.; Zhang, D. Influence of cryptogamic soil crusts on accumulation of soil organic matter in Gurbantunggut Desert, northern Xinjiang, China. Acta Ecol. Sin. 2005, 25, 3420-3425. (In Chinese)

12. Cui, Y.; Lv, Z.; Li, B. Physico-chemical properties of soilmicrobiotic crusts on Erdos plateau. Soils 2004, 36, 197-202. (In Chinese)

13. Guo, Y.; Zhao, H.; Zuo, X.; Drake, S.; Zhao, X. Biological soil crust development and its surface soil properties in the process of dune stabilization, Inner Mongolia, China. Environ. Geol. 2008, 54, 653-662. [CrossRef]

14. Belnap, J.; Gillette, D.A. Vulnerability of desert biological crusts to wind erosion: The influences of crust development, soil texture and disturbance. J. Arid Environ. 1998, 39, 133-142. [CrossRef]

15. Fang, H.; Cai, Q.; Chen, H.; Li, Q.Y. Mechanism of formation of physical soil crust in desert soils treated with straw checkerboards. Soil Tillage Res. 2007, 93, 222-230. [CrossRef]

16. Li, W.; Ren, T.; Zhou, Z.; Liu, J. Study on the soil physicochemical characteristics of biological crust on sand dune surface in Gurbantunggut Desert, Xinjiang Region. J. Glaciol. Geocryol. 2005, 27, 619-627. (In Chinese)

17. Huang, L. Spatial distribution of Agriophyllum squarrosum Moq. (Chenopodiaceae) in the straw checkerboards at a revegetated land of the Tengger Desert, northern China. J. Arid Land 2017, 9, 176-187. [CrossRef]

18. Byers, J.E.; Cuddington, K.; Jones, C.G.; Talley, T.S.; Hastings, A.; Lambrinos, J.G.; Crooks, J.A.; Wilson, W.G. Using ecosystem engineers to restore ecological systems. Trends Ecol. Evol. 2006, 21, 493-500. [CrossRef] [PubMed]

19. Belnap, J.; Lange, O.L. Biological Soil Crusts: Structure, Function and Management; Springer: Berlin, Heidelberg, 2001.

20. Belnap, J. The potential roles of biological soil crusts in dryland hydrologic cycles. Hydrol. Process. 2006, 20, 3159-3178. [CrossRef]

21. Geddes, N.; Dunkerley, D. The influence of organic litter on the erosive effects of raindrops and of gravity drops released from desert shrubs. Catena 1999, 36, 303-313. [CrossRef]

22. Guo, Y.; Zhao, H.; Zhao, X.; Zuo, X.; Li, Y. Study on crust development and its influences on soil physicochemical properties in Horqin Sand. J. Soil Water Conserv. 2007, 21, 135-139. (In Chinese)

23. Bowker, M.A. Biological soil crust rehabilitation in theory and practice: An underexploited opportunity. Restor. Ecol. 2007, 15, 13-23. [CrossRef] 
24. Vies, H.A. Understanding dryland landscape dynamics: Do biological crusts hold the key? Geogr. Compass 2008, 2, 899-919. [CrossRef]

25. Ball, D.F. Loss-on-ignition as an estimate of organic matter and organic carbon in non-calcareous soils. Eur. J. Soil Sci. 1964, 15, 84-92. [CrossRef]

26. Baethgen, W.E.; Alley, M.M. A manual colorimetric procedure for measuring ammonium nitrogen in soil and plant Kjeldahl digests. Commun. Soil Sci. Plan 1989, 20, 961-969. [CrossRef]

27. Lehtola, M.J.; Miettinen, I.T.; Vartiainen, T.; Rantakokko, P.; Hirvonen, A.; Martikainen, P.J. Impact of UV disinfection on microbially available phosphorus, organic carbon, and microbial growth in drinking water. Water Res. 2003, 37, 1064-1070. [CrossRef]

28. Cooper, J.A. The flame photometric determination of potassium in geological materials used for potassium argon dating. Geochim. Cosmochim. Acta 1963, 27, 525-546. [CrossRef]

29. Institute of Soil Science, Chinese Academy of Sciences (ISSCAS). Physical and Chemical Analysis Methods of Soils; China Shanghai Science Technology Press: Shanghai, China, 1978; pp. 89-120. (In Chinese)

30. Boer, M.; Puigdefábregas, J. Effects of spatially structured vegetation patterns on hillslope erosion in a semiarid Mediterranean environment: A simulation study. Earth Surf. Process. Landf. 2005, 30, 149-167. [CrossRef]

31. Park, H.M. Univariate Analysis and Normality Test Using SAS, Stata and SPSS; The Trustees of Indiana University: Indianapolis, IN, USA, 2015.

32. Zhang, S.; Ding, G.; Gao, G.; Yu, M.; Zhao, Y.; Wu, G.; Wang, L. Effects of straw checkerboard barrier in different setting years on ecological restoration. Sci. Soil Water Conserv. 2018, 16, 10-15. (In Chinese)

33. Zou, K.; Deng, X.; Li, F.; Yu, Q.; Dai, Y.; Xiao, Z. pH of Shaoyang tobacco-growing soils and their relations with nutrients. J. Beijing Univ. Agric. 2014, 29, 6-9.

34. Escudero, A.; Martínez, I.; Cruz, A.D.L.; Otálora, M.; Maestre, F.T. Soil lichens have species-specific effects on the seedling emergence of three gypsophile plant species. J. Arid Environ. 2007, 70, 18-28. [CrossRef]

35. Xue, Y.; Yan, D.; Li, G. The research of desert microphytic crusts on Erdos plateau. J. Inner Mong. Agric. Univ. 2007, 28, 102-105. (In Chinese)

36. Wang, Y.; Liu, K.; Qu, J. Effects of Sand Barriers on vegetation and soil nutrient in sand dunes. J. Dessert Res. 2019, 39, 56-65. (In Chinese)

37. Li, X.; Xiao, H.; He, M.; Zhang, J. Sand barriers of straw checkerboards for habitat restoration in extremely arid desert regions. Ecol. Eng. 2006, 28, 149-157. [CrossRef] 